INVITED REVIEW

\title{
Testosterone levels in healthy men and the relation to behavioural and physical characteristics: facts and constructs
}

\author{
M Zitzmann and E Nieschlag \\ Institute of Reproductive Medicine of the University, D-48129 Münster, Germany \\ (Correspondence should be addressed to E Nieschlag, Institute of Reproductive Medicine of the University, Domagkstr 11, D-48129 Münster, Germany; \\ Email:nieschl@uni-muenster.de)
}

\begin{abstract}
This review summarises the correlations between testosterone levels and male physical appearance and behaviour. Methodological shortcomings concerning the measurement of testosterone could limit the value of these findings. In addition, testosterone measured in body fluids represents only one step in the cascade of action from production to biological effect, and could therefore provide only a limited view of the complexity of physiological events. Testosterone levels are influenced by conditions that are partly controlled or initiated by the hormone itself, but also by circumstances beyond hormonal or individual control. Different kinds of behaviour are not only subject to influence by environment, but also androgens can reinforce the particular kind of conduct and the behavioural impact can wield negative or positive feedback on testosterone secretion. Therefore, both generalisation and individualisation of study results will lead to doubtful conclusions and prejudices. Results of such studies must be viewed with caution, and over-simplification as well as over-interpretation should be avoided.
\end{abstract}

European Journal of Endocrinology 144 183-197

\section{Introduction}

Testosterone is the best known hormone outside professional medicine. The popularity of the male sex hormone derives from the fact that it acts in all organs and systems and has a significant influence on important aspects of life such as physical appearance, behaviour, mentality, abilities, sexuality and social status. The media are focussed on testosterone and while they disseminate much information, they also indulge in speculations on its effects, as highlighted by the following quotation: 'the He hormone...has become a metaphor of manhood...it affects every aspect of our society, from high divorce rates and adolescent male violence to exploding cults of bodybuilding...' (1). Often scientific publications reinforce these speculations by finding yet another connection between high or low testosterone levels and physical or mental variables. However, because man consists of more than unrelated components, the question arises whether the onedimensional ups and downs of serum testosterone levels are sufficient to explain the complexities of (hu)man life and whether the supposed/alleged connections may not be oversimplifying and misleading when generalised or applied to healthy eugonadal individuals not exposed to exogenous testosterone. The multitude of associations of low or high testosterone levels with behavioural and physical characteristics makes one wonder whether one hormone can be responsible for so many features and facets of life. In the current article we will review these associations as described in healthy men based on representative and, as far as possible, controlled studies, and point out methodological pitfalls and deficiencies in interpreting results.

\section{Association of endogenous testosterone levels with physical exercise}

There are numerous reports on the effects of physical exercise on testosterone levels and vice versa. Many of these studies lack control groups, have very low numbers of participants or combine different effectors on hormone levels. Moreover, a distinction has to be made between physical exercises requiring endurance and those that train strength.

\section{Endurance training/physical stress}

Endurance training can have a prolonged effect on androgen levels. Controlled trials involving men undergoing endurance training and control groups of sedentary men give the impression of generally lowered 
androgen levels in exercising men. Normal feedback regulation would require luteinizing hormone (LH) levels to rise with falling testosterone levels. A suppression in the regulatory axis could explain that differences in gonadotropin levels are rarely seen in exercising vs. sedentary men despite marked differences in testosterone levels $(2-7)$.

That training and competition in physical endurance also means exposure to physical stress is shown in controlled settings observing male participants of ultramarathon competitions. Testosterone levels decrease during contests, whereas LH levels do not change. In addition, cortisol levels, as a prominent endocrine marker for physical or mental stress exposure, are elevated significantly in runners in comparison to controls (8). This is confirmed by other studies on stress and overtraining (9-12).

Patterns of the mental/psychological and physical stress response of the hypothalamic-pituitary-adrenal (HPA) axis are the same within one individual. Differential reactivity is seen between so-called high and low responders (13). This may apply to the HPA too; the lowering effect of endurance training on testosterone levels may be seen as a part of a general response pattern to stress in an individual. As described below, mental stress has a negative impact on testosterone secretion. In settings combining the mental and physical aspects of stress, testosterone can drop to clearly hypogonadal levels $(14,15)$. The decrease of testosterone levels under stressful situations is usually not sufficiently answered by the pituitary to compensate for the decrease.

\section{Strength training}

In men, muscle mass and strength are often described as being associated with testosterone levels. This applies to older men as well as to adolescents $(16,17)$. Strength training can have an acute effect on endocrine functions. Measurements immediately and $5 \mathrm{~min}$ post-exercise show an age-dependent increase in testosterone levels (18-22). Persons continuously involved in strength training, however, do not show significant changes in testosterone levels $(20,23,24)$. Overtraining as a physical stress factor may decrease androgen levels. Abuse of exogenous testosterone for anabolic effects can also affect other parameters and will not be discussed further (22, 25-29).

\section{Mental stress}

The release of cortisol by activation of the HPA axis as a reaction to mental stress is well documented (23). Similarly, stress responses by the HPA axis are also seen. This applies not only to physical stress but also to psychologically disturbing events.

Stressful situations as experienced during work, before tournaments or anticipating exams have been shown to decrease testosterone levels (30-36). Stress release, on the contrary, can have an elevating effect on androgen levels, which is demonstrated by a controlled study involving volunteers practising transcendental meditation (37). The same effect was seen in men undergoing workplace reorganisation and threatened by unemployment. After the workplace situation changed for the better, testosterone levels clearly rose; however, there was a marked variation between subjects (38).

It remains unclear whether the drop of testosterone levels in exposure to mental stress is caused by decreased LH secretion or whether an adequate response at the pituitary level is not present. An additional impact factor might be the increased glucocorticoid secretion observed in stressful situations (due to increased corticotropin-releasing hormone production), which may be responsible for downregulated testosterone biosynthesis in the Leydig cell (39).

\section{Aggression}

Aggression is one of the aspects of human behaviour that is often linked to testosterone levels; knowledge and assumptions are often derived from animal models. In a representative study, ten cynomolgus monkeys received injections of either testosterone propionate or a sham solution. Testosterone administration led to a significant increase in aggression, which was mediated by social status. Dominant animals were much more likely to present aggressive behaviour than subordinate ones (40).

In male prison inmates selected for high levels of aggressiveness, testosterone levels have often been described as being linked with violent behaviour (4147), whereas correlations between testosterone and aggression were low when hostility inventories were applied in volunteers who had not been in conflict with the law $(48,49)$. This contradiction was explained by the fact that physically violent behaviour leading to legal prosecution is likely to occur in a desolate socioeconomic environment and can itself induce testosterone secretion (and thus result in a selection bias for many studies involving prison inmates). The induction of testosterone secretion by external stimuli of aggression should be seen to be dependent on additional factors, such as culture and education; social background can influence these reactions, as shown in students from the northern and southern parts of the USA, the latter describing themselves as having grown up in a 'culture of honour' in which insults diminish a man's reputation. When the volunteers were subjected to verbal insult, the Southerners reacted with significantly more aggressive and dominant behaviour, which was correlated with their rising serum testosterone levels (50). In a socially homogeneous group of German volunteers, levels of saliva testosterone did not change 
during exposure to aggressive and violent films (51). It is possible that an environment constantly provoking aggressive behaviour may lead to various reactions and qualities of aggressive responses, which in turn may lead to differential hormonal secretion patterns (52).

There are strong indications that there is an interdependent feedback mechanism between testosterone and aggression that is modified by experiences of victory and defeat (see below), as well as by education, cultural and socioeconomic background. It seems that the subject's own behaviour can cause and reinforce the type of hormonal activity that stimulated the behaviour in the first place. This pattern of positive feedback seems to be necessary to maintain an emotionally stable personality. Emotional instability was found to be related to a greater variability in testosterone secretion (53).

The immense variety of individual response patterns to androgens is demonstrated by a controlled trial in which exceptionally high doses $(600 \mathrm{mg} /$ week $)$ of testosterone cypionate were administered; maniac effects were reported in only $16 \%$ of the men. The psychological behaviour of the others remained unremarkable (54). Effects of external administration of testosterone on aggressive behaviour are controversial (55-58).

\section{Depressive illness}

In hypogonadal men whose often lethargic or depressive mood significantly improved under testosterone therapy (59), studies exploring the relationship between gonadal function and depressive episodes showed that testosterone secretion as well as mean levels were decreased significantly in patients $(60,61)$. The relationship of major depression to stress becomes evident by the increased baseline activity of the HPA axis in patients with the disease. Urinary cortisol secretion is significantly increased in depressive patients. This phenomenon is also observed in posttraumatic stress disorder, which can lead to depressive states $(62,63)$. Decreased testosterone levels in depressive illness can be seen as a permanently downregulated secretion, partially maintaining a state of mood that initiated it in the first place. The effects of depressive illness on androgen levels and vice versa are probably closely related to general stress reactions. The mutual character of the feedback mechanism found for testosterone and behaviour may also become evident in this aspect. External administration of testosterone is therefore considered for the treatment of depressive states $(64,65)$.

\section{Cognitive abilities}

Gender differences in cognitive function tests have been widely reported: men tend to excel in fields of spatial cognition, whereas women show greater abilities in verbal fluency $(66,67)$. Many factors influence the development of these abilities, such as environment, education, cultural background and inherited factors, but sex hormones also play a role in development and maintenance of cognitive functions. Variation and overlapping scores between genders show the limited extent of this impact; to a much higher degree, an individual's cognitive abilities are derived from experience, education and inheritance (68).

\section{Visuo-spatial cognition}

Gender differences in spatial cognition have been described frequently; males excel especially in tasks of mental rotation (69-73). Compared with women, a stronger cerebral laterization concerning various tasks has been observed (74). Right hemisphere specificity in mental rotation procedures $(75,76)$ can explain the observed difference between genders in such tasks (69, $72)$. This is also the case in children of both sexes, suggesting an influence of differential foetal sex hormone levels on the formation of brain architecture (70). In healthy men, positive associations of testosterone levels with scores achieved in such tests have been reported $(77,78)$, but a curvilinear relationship between androgen levels and spatial cognition in humans has also been discussed (79) and some studies report negative relationships $(80,81)$. An association between the ultradian rhythms of gonadotropin and androgen secretion and performance levels of spatial cognition seems to exist (82).

Only drastically altered testosterone levels yield a coherent picture. In female-to-male transsexuals testosterone has an enhancing, not quickly reversible, effect on spatial ability performance; an opposite effect is reported for male-to-female transsexuals receiving androgen-ablation (83). In hypogonadal men, visuospatial abilities are impaired and most studies report improvement during androgen substitution (84-88). Cerebral neuroimaging suggests that this improvement is due to an androgen-mediated activating effect on cerebral structures involved in evaluating data of visuospatial content, such as the ventral visual processing stream (89). As long as subjects are not clearly hypogonadal, the learning effects of such tasks are likely to outweigh fluctuations in androgen levels.

\section{Verbal skills}

Indications are that testosterone levels seem to be negatively correlated to verbal skills in males (88). Testosterone substitution in elderly males can block the practising effect in verbal fluency (90). Female-to-male transsexuals show a steady decline in verbal fluency under testosterone administration (83). Corresponding effects were seen in male-to-female transsexuals receiving oestrogen treatment; their verbal skills increased in comparison to controls waiting for 
hormone treatment (91). It has also been demonstrated that oestrogens can enhance verbal skills in postmenopausal women (92). In healthy elderly men, oestrogen levels are positively associated with verbal abilities (93).

Sex hormone-dependent brain formation processes take place during the prenatal period. In later life, androgens and estrogens seem to be able, and necessary, to activate neural pathways established earlier (94). This refers to the distinction between the states of eu- and hypogonadism, but the effects of shifting hormone levels within the eugonadal range are not distinguishable in individuals.

\section{Musical skills}

Empirical data concerning musical skills and testosterone levels are presented in an evaluation of 117 adults and 120 adolescents. Musical abilities were enhanced in men with low testosterone levels and in women with high testosterone levels relative to normal ranges (95). Because many factors influence hormone levels, it is difficult to assign an optimal testosterone range (which would have to be maintained) for the development of musical abilities (96).

\section{Social status}

Psychoendocrinological aspects of an individual's social status can be approached by focussing either on hormonal influences on the regulation of social behaviour or vice versa. Social interaction may elicit different activation pathways depending on former experiences of the respective individual. Rank in primates has been extensively studied. For example, in mandrills and squirrel monkeys, social rank is said to be correlated with testosterone levels. In squirrel monkeys, external testosterone cannot change rankspecific behaviour $(97,98)$. Regarding man, studies involving non-primate mammals are of restricted value, because these animals are often subject to seasonal influences.

In boys, a positive association of testosterone with social dominance as assessed by peer-rating was described. Inter-individual variation was high in these samples $(99,100)$. An occupation involving high demands and low decision latitude, indicating lower social status, was found to be associated with lower testosterone levels (waiters compared with physicians and air traffic controllers). Variable degrees of stress as a lowering vector of testosterone levels (see above) should be taken into consideration when regarding different occupational aspects in each subgroup (101).

To determine a possible role of testosterone in status ranking, chess players were tested before and after competition. Before and after tournaments, winners/ winners-to-be had higher testosterone levels than losers (102). Similar results in regard to postcompetition levels were described during tennis matches and wrestling competitions $(103,104)$. Also a history of previous success or membership in the host team can lead to an elevation of testosterone levels after the match (105). This indicates that personal experience of success as well as the feeling of dominance owing to 'territorial advantage' can influence the pattern of endocrine response to a competitive situation. An interdependence with other factors such as aggression and 'anti-social' behaviour, described as low levels of intraception, nurturance and responsibility, has been demonstrated (43). Socioeconomic status has been described as a moderating variable in testosteronebehaviour relationships. The constellation of dominance, competitiveness and sensation-seeking behaviour was found to influence the correlation of high testosterone levels with either 'anti-social' or 'prosocial' behaviour, the latter being dominant in individuals with higher socioeconomic status (106). From these data, a sequence of events was inferred: high testosterone levels could lead to aggressive, 'antisocial' behaviour, causing low education levels and thus low occupational status (107). Such a sociological analysis resulting in a singular causal chain is questionable, since hormonal feedback mechanisms and external factors, such as environmental, social and genetic influences should not be disregarded.

\section{Ethnic differences}

In violent sexual offenders, serum testosterone levels were significantly higher in the group of native Americans than in Caucasians (41, 108). Such analyses have led to conclusions that a predisposition to crime may be genetically based, have consistent racial variations and may be expressed as serum testosterone levels and brain size, which are supposed to cause different crime rates in Asian, Caucasian and African-Americans (109).

Not biased by selection of subjects in conflict with the law, other studies demonstrate similar testosterone levels in African-American and Caucasian American men. $(110,111)$. In contradiction to the so-called predisposition theories on crime rates and race, another study involving 1127 men and adjusting data for age and body mass index (BMI), showed levels of total and bioavailable testosterone to be highest in Asian Americans, followed by African-Americans and lowest in Caucasian Americans (112). A greater risk for African-Americans of developing prostate cancer in comparison to Caucasians or Asians seems to exist; testosterone levels are not different, but hereditary factors concerning polymorphism in androgen receptors and $5 \alpha$-reductase activity are held responsible (113). Supporting results were found comparing Americans of Chinese or Caucasian origin, explaining the lower expression of beard and body hair in Asians (114). Ethnic differences in sex hormone-dependent 
features are obviously restricted to genetic polymorphisms, leading to differential enzyme and receptor activity, but not to different testosterone levels (115, 116). The cultural background can also influence testosterone levels through nutritional factors (see Dietary influences; 117).

\section{Sexuality}

Androgens play an important role in male sexuality. This is impressively demonstrated by activation/reactivation of sexual activity in hypogonadal men receiving substitution therapy. Self-reported decline of sexual functions starts at levels $<5-8 \mathrm{nmol} / \mathrm{l}(118-120)$.

\section{Behaviour in male heterosexuality}

In eugonadal men, testosterone levels have no significant association with different kinds of sexual activity, except for frequency of masturbation (48). Similar results were reported in couples; in men there was no correlation of testosterone levels to sexual activity of any kind but in women sexual gratification, as well as frequency of intercourse, were positively related to testosterone levels (121). It can be assumed that in men testosterone levels are positively linked to libido, but that sexual activity in the partnership is moderated by the relationship itself. In eugonadal men, external administration of high doses of testosterone was said to increase sexual awareness and arousability, but this is not reflected in any general modification of sexual activity $(122,123)$.

As seen with other behavioural aspects, a mutual relationship between testosterone levels and specific behaviour (in this case sexuality) can be discerned; a sexual stimulus can increase testosterone levels. This has been demonstrated in male volunteers exposed to films with sexual content $(51,124)$. Cerebral neuroimaging during such films showed sexually stimulated activation of temporal areas to be associated with testosterone levels. This may reflect a positive feedback effect, as testosterone is released by sexual stimulation and can lead to further activation of these areas (125). These data are consistent not only with natural phenomena observed during sexual arousal, but also with the mutual character of hormone-behaviour interaction.

\section{Behaviour in male homosexuality}

It has been suggested that testosterone levels might be decreased in homosexual men. Most of the earlier studies did not find significant differences in total serum testosterone levels but tendencies towards lower free testosterone and higher gonadotropins in comparison to heterosexual men were described (126-128).

A differential organisational effect of possibly subnormal testosterone levels during foetal brain development in homosexual men has been discussed. Thus, differences in LH secretion to an oestrogen stimulus, a dissimilar gonadotropin-releasing hormone pulse frequency and lower neuronal density of hypothalamic nuclei involved in sexual activity, which have been reported in homosexual men, could be explained (129135). However, homosexuality is as varied and multifold in its behavioural aspects as heterosexuality and postnatal hormone levels do not seem to play a different role from that in heterosexuality.

\section{Violent sexual offences}

When sexual offenders receive anti-androgenic gestagens, a clearly hypogonadal state is achieved and sexual activity decreases and, with it, criminal potential. The rate of re-offence is much higher in delinquents not receiving, or discharged from, medication (136). In violent sexual offenders, testosterone serves as a catalyst to initiate the expression of aberrant desires already present, and withdrawal of androgens can inhibit delinquency. The conclusion that higher testosterone levels within or above the normal range would therefore mean a higher risk for sexual aggression cannot be drawn from this information.

Comparing testosterone levels between violent rapists with non-violent sexual offenders and controls has yielded contradictory results (137-139). Sexual aggression as expressed in viewing time of slides with sexually aggressive content vs. control slides showed a slightly positive correlation with free testosterone serum levels (140).

Case reports of patients with low testosterone levels and aggressive sexual behaviour towards women have been published (141-143). Testosterone substitution of these patients who present with often clearly hypogonadal androgen levels can cause aggression to disappear (144). Adaption to psychosexual behaviour that is considered normal and cessation of feelings of inferiority evolve during testosterone substitution (145, 146). This observation stresses the importance of environmental and social factors on sexually aberrant behaviour.

\section{Advancing age}

'Andropause' is a term appearing recently in various publications. Alluding to the female menopause, it indicates that in men there could be a precipitous and definite end to gonadal steroid production and fertility, as it occurs in women. In healthy men, however, the decrease in androgen production is rather a slow process. It was shown that with advancing age the proportion of men presenting with testosterone levels in the sub-normal range increases significantly. Low levels can be found in $<1 \%$ of men aged below 40 years, but in $>20 \%$ of men older than 60 years and $>40 \%$ in men above 80 years. These results are confirmed by longitudinal studies. Inter-individual variation is 
marked and men aged 70 years can still be fertile (147-154). Increased levels of sex hormone binding globulin (SHBG) further decrease bioavailable testosterone. Reduced levels of growth hormone and insulin-like growth factor 1 , which inhibit SHBG production in hepatocytes, are responsible for this phenomenon (152). A low protein diet may elevate SHBG levels in elderly men (155). Although healthy older men are more likely to present with lower testosterone levels than younger men, many men aged over 80 years (about 55\%) still have relatively normal androgen values. With chronic diseases in different subpopulations, other pictures emerge (see below).

\section{Weight}

The BMI, defined as $\mathrm{kg} / \mathrm{m}^{2}$, is a useful tool to measure obesity. For the whole range of BMI values there is a negative correlation to serum testosterone levels, but levels of SHBG are also decreased. Thus, levels of bioavailable testosterone remain almost unchanged (156, 157); only in extreme obesity (BMI > $40 \mathrm{~kg} / \mathrm{m}^{2}$ ) do testosterone levels decrease to a greater extent than SHBG levels.

Leptin as a messenger of the body's energy resources is positively related to $\mathrm{BMI}$; it is inversely correlated to serum testosterone levels (158). Leptin is most probably involved in the regulation of the hypothalamic-pituitary-gonadal (HPG) axis. Although there is a negative correlation between leptin and serum testosterone levels under normal nutritional conditions, another picture emerges in hunger and massively decreased weight; in severe cases, these conditions can affect the HPG axis. Gonadotropins and steroids are reduced, often to clearly hypogonadal levels. Reduced leptin levels and the interaction with neuropeptide $\mathrm{Y}$ are held responsible for this phenomenon. In fasting rhesus monkeys, external leptin can restore the function of this axis via normalising (increasing) LH pulse frequency (159).

\section{Dietary influences}

The effects on hormone levels of fibre-rich, vegetarian diets and 'western-type' diets containing meat protein and more fat have been described. Urinary secretion of androgens (representing a fraction of bioavailable testosterone) in black and white North American men and rural black South African men was found to be significantly higher in those subjects living on a meatrich western diet. Swapping nutritional habits had corresponding effects (117). Comparing total serum testosterone levels in omnivorous men to those on a vegetarian diet showed no differences, but in the latter group there were significantly higher levels of SHBG, leading to decreased levels of bioavailable testosterone (160). The kind of diet is most likely to influence the fraction of bioavailable testosterone, but not total levels of this hormone (161-165).

\section{Influence of altitude/air pressure}

A comparison between boys living at $3600 \mathrm{~m}$ or $420 \mathrm{~m}$ showed significantly lower levels of saliva testosterone in the first group (100). Corresponding results were reported from men changing the altitude of their place of residence ((166); but also see $(11,167$, 168)). Considering the pattern of hormonal change, exposure to low air pressure could mean a type of physical stress that has similar effects as endurance training.

\section{Voice}

Mutation of the male voice to a lower frequency occurs during puberty. It is well established that castrates, when orchiectomized before sexual maturation, maintain the high voice of a child. During puberty, there is a clear association between the decreasing frequency of the voice, testicular volume and testosterone levels (169, 170). This correlation can also be found in adult males. In male singers, the deeper voices of bass and baritone singers are related to higher plasma testosterone levels in comparison to tenors. As the deepness of the voice depends on the size of the larynx, it reflects the hormonal situation and organ sensitivity during sexual maturation. That testosterone secretion can be preserved at its relative level is shown in groups of singers 50-70 years of age (171). Due to marked interindividual variation, estimation of testosterone levels by vocal register is not possible in individual persons.

\section{Hair pattern}

In contrast to hypogonadal men, many men within the eugonadal range tend to develop balding patterns of the scalp whereas beard growth is not inhibited. Hair growth in children shows that display of so-called terminal hair is not androgen-dependent. In puberty, pubic and axillary hair develop, these follicles being dependent obviously on sexual hormones. The amount of body hair is highly variable and differs between races and families. The degree of male balding is also inherited (172). Density and pattern of distribution of androgen receptors as well as $5 \alpha$-DHT levels and $5 \alpha$ reductase activity also play a pivotal role in secondary sex characteristics (173-175). Men without any sign of balding and no beard growth are most likely to be androgen-deficient or -insensitive.

In eugonadal men, a significant association of free testosterone levels with the development of vertex and frontal baldness was reported (176). In another group, healthy young men showed a disposition to balding in those subjects with an increased ratio of $5 \alpha-\mathrm{DHT} /$ testosterone. Absolute serum testosterone levels were 
not associated with balding patterns (177). Differences in beard growth, body hair and balding seen between races are probably determined by various degrees of $5 \alpha$ reductase activity; the ratio $5 \alpha$-DHT:testosterone was higher in Caucasians than in Asians living in the US and Canada (112).

\section{Influence of systemic non-gonadal diseases on testosterone levels}

Major burns, myocardial or cerebral infarctions or traumatic injuries as severe, acutely life-threatening diseases cause extreme stress to the individual. Pulsatile LH secretion is often (reversibly) diminished in these patients, leading clinically to hypogonadal states (178). Gonadal function is also influenced by inflammatory mediators (179). Uraemic hypogonadism can be caused by chronic renal diseases via the pituitary (180). Subnormal testosterone levels but gonadotrophin levels within the eugonadal range can be present in chronic liver diseases (181). Gastrointestinal diseases resulting in maldigestion or malabsorption and, therefore, undernutrition can also have a suppressive effect on testosterone secretion (182). Hyperthyroidism, haematological and autoimmune diseases can also alter androgen production $(183,184)$.

\section{Influence of medications on testosterone levels}

There are multiple pathways by which medications can influence the secretion or the action of androgens. Opiates can alter LH pulsatility; steroidogenic enzymes can be inhibited by ketoconazole. Androgen receptors can be blocked by cimetidine or spironolactone. Testosterone metabolism can be increased via hepatic enzyme induction by barbiturates and other anticonvulsants (183). The use of medication can, especially in uncontrolled, cross-sectional studies, contribute to a bias distorting the results concerning endocrine secretion patterns.

\section{Influence of recreational drugs on testosterone levels}

In large study groups, tobacco smoking has been associated with elevated testosterone levels $(185,186)$. The effect of marijuana smoking has no significant effect on gonadotropin or testosterone levels (187). Excessive alcohol consumption has toxic effects on hepatocytes and leads to hypothalamic dysfunction associated with lower testosterone levels. Moderate consumption of alcohol will have no effect, but a personality trait of sensation-seeking behaviour has been described as associated with higher testosterone levels and higher frequency of alcohol consumption (188). Chronic abuse of cocaine will lead to an impairment of hypothalamic-pituitary function and

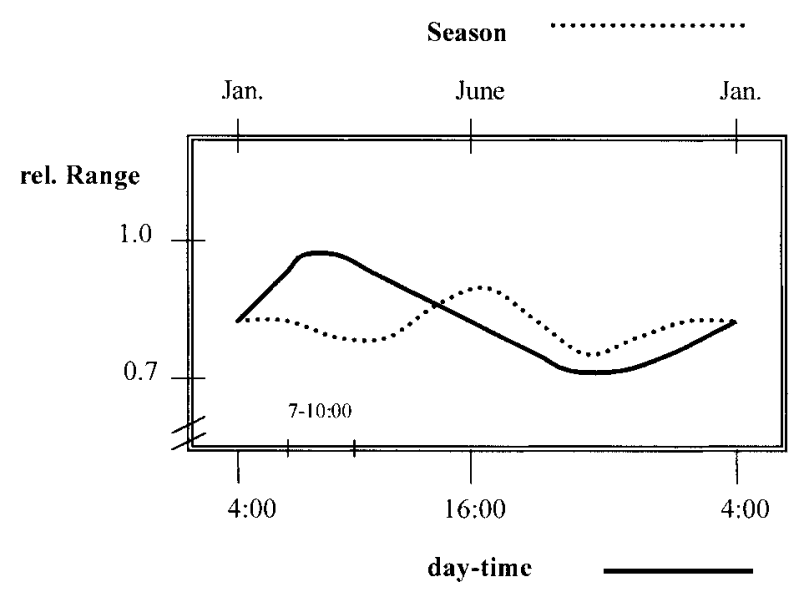

Figure 1 Pattern of relative changes in serum testosterone levels due to diurnal (solid line) and seasonal (dotted line) variations of testosterone secretion (derived from (191-197, 201-203)).

further to decreased testosterone levels (189). The same applies to chronic abuse of opioids, for example, heroin (190). In the cases of long-term illegal drug abuse or excessive consumption of legal substances, other factors, such as an impaired nutritional state and adverse socioeconomic circumstances, will also influence the endocrine pattern.

\section{Discussion}

Many of the studies reviewed here have a controlled design; some, in the case of hormone administration, involve placebo groups. Most of the cross-sectional studies have examined data from larger numbers of participants. However, methodological problems of measuring testosterone in body fluids are often overlooked. Serum testosterone levels are determined routinely by radioimmunoassays or luminescence immunoassays. Because there is a strong diurnal variation with morning concentrations being approximately 20-30\% higher than evening values (Fig. 1; (191-197)), samples should always be taken during the morning hours. Only then will single point samples be representative (198-200). Seasonal variations of testosterone levels should also be taken into consideration, at least in studies comparing several groups at different time points (Fig. 1; (201-203)). Because testosterone is a small molecule and present in relatively low concentrations, it is not surprising that there is marked inter- and intra-assay bias and variation (Fig. 2). Therefore, comparing testosterone levels determined with different assays and/or in different laboratories becomes questionable. Quality control uncovers this problem, but has not contributed to its solution. Direct measuring of free testosterone concentrations, which are found at much lower concentrations than the total amount of this steroid (about 2\%), is subject to even greater difficulties. The 


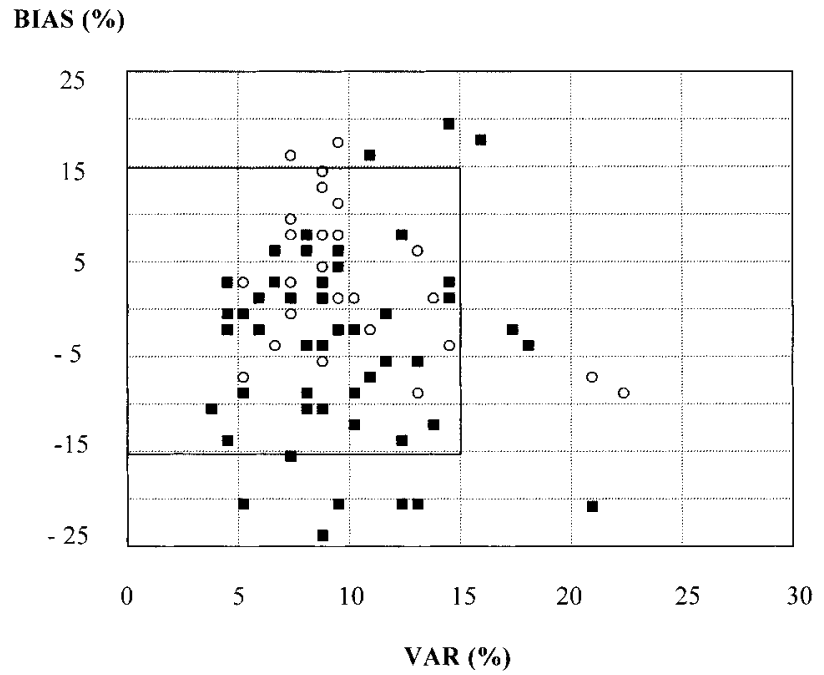

Figure 2 Bias and variation of different testosterone assays in males, derived from a quality control programme on steroid assays with 131 participants (222). This means, e.g. when a sample with a 'true' value of total serum testosterone of $12 \mathrm{nmol} / \mathrm{l}$ is measured in a laboratory with bias of $15 \%$ and variation of $15 \%$, values between 11.7 and $15.9 \mathrm{nmol} / \mathrm{l}$ are returned. In another laboratory with bias $-15 \%$ and variation $15 \%$ the same sample is measured between 8.7 to $11.7 \mathrm{nmol} / \mathrm{l}$. Thus, for the 'true' value of $12 \mathrm{nmol} / \mathrm{l}$ all values between 8.7 and $15.9 \mathrm{nmol}$ were still acceptable for this quality control programme. Open circles, non-isotopic methods; solid squares, RIA; acceptable range marked by full lines.

same applies to determination of testosterone levels from saliva samples, which are correlated with free testosterone in serum. Reliable assays are still under development (204). Additional measurement of SHBG and its ratio to total testosterone is more reliable when estimating the bioavailable fraction of testosterone $(198,205)$. In summary, although assays have been available for over 30 years, measurement of serum testosterone is still relatively unreliable and represents a significant bias when interpreting results and correlating them with biological phenomena. Unfortunately, peer-reviewed journals as the ultimate filter have not contributed much to improve the reliability of published values. Therefore, all reported variations of testosterone levels and their associations with physical and mental aspects must be viewed very critically.

When interpreting testosterone levels, it is often overlooked that levels of the hormone in body fluids are only a small and transitory step in the cascade of hormone action from production to biological effect. The Leydig cell as the primary source of androgens in the male is subject to influence by various substances such as testosterone itself (206), oestradiol (207) and glucocorticoids, which are also produced in a diurnal rhythm (208). Transforming growth factor- $\beta$, basic fibroblast growth factor and tumour necrosis factor- $\alpha$ are other substances that vary with extratesticular changes (i.e. as inflammation markers) and can decrease Leydig cell steroidogenic responsiveness
Table 1 Testosterone levels: absurdities and prejudices created by applying various one-dimensional associations to individuals. An overview of study results examining singular qualities. Positive associations of testosterone levels of physical and behavioural characteristics.

\begin{tabular}{|c|c|c|c|c|}
\hline \multirow[b]{2}{*}{ Aspect } & & \multicolumn{3}{|c|}{ Range of testosterone leve } \\
\hline & & Low & Medium & High \\
\hline Hair pattern & $\begin{array}{c}\text { Balding } \\
\text { Beard growth }\end{array}$ & & 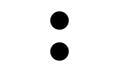 & ๑ొ \\
\hline Sexuality & $\begin{array}{c}\text { Non-abusive } \\
\text { Criminal aspects }\end{array}$ & & $\bullet$ & $\stackrel{\bullet}{\bullet}$ \\
\hline $\begin{array}{l}\text { Physical } \\
\text { abilities } \\
\text { Stress } \\
\text { Depression }\end{array}$ & $\begin{array}{l}\text { Strength } \\
\text { Endurance }\end{array}$ & $\begin{array}{l}0 \\
0 \\
0\end{array}$ & $\bullet$ & $\bullet$ \\
\hline $\begin{array}{l}\text { Social } \\
\text { behaviour }\end{array}$ & $\begin{array}{l}\text { Aggression } \\
\text { Physical violence } \\
\text { Dominance } \\
\text { Submission }\end{array}$ & $\bullet$ & $\stackrel{0}{0}$ & $\begin{array}{l}\bullet(\bullet) \\
\bullet(0) \\
\bullet(0)\end{array}$ \\
\hline $\begin{array}{l}\text { Cognititive } \\
\text { traits }\end{array}$ & $\begin{array}{l}\text { Spatial cognition } \\
\text { Verbal abilities }\end{array}$ & $\bullet$ & $\bullet$ & \\
\hline Voice & $\begin{array}{l}\text { Deep } \\
\text { High }\end{array}$ & $\bullet$ & $\bullet$ & $\bullet$ \\
\hline $\begin{array}{l}\text { Altitude of } \\
\text { habitation } \\
\text { Ageing }\end{array}$ & $\begin{array}{l}\text { Mountains } \\
\text { Sea level }\end{array}$ & • & $\bullet$ & \\
\hline Diet & $\begin{array}{l}\text { Vegetarian } \\
\text { 'Western' }\end{array}$ & $\bullet$ & • & \\
\hline Ethnic group & $\begin{array}{c}\text { African } \\
\text { Caucasian } \\
\text { Asian } \\
\text { Native American }\end{array}$ & $(\odot)$ & $(\bullet)$ & $(0)$ \\
\hline
\end{tabular}

- Positive association; $\bullet$ relatively strong association; (๑) questionable.

(209-211). Androgen receptor polymorphisms (e.g. CAG repeats) can modify testosterone action. The length of the CAG repeats varies among individuals and these polymorphisms are believed to be related to the transcriptional activity of the activated receptor. This applies to forms of prostate cancer (212), breast cancer (213) and benign prostate hyperplasia (214, 215). It can be assumed that CAG repeat length influences androgen susceptibility in other tissues as well. Tissue-specific androgenicity is not solely dependent on testosterone levels; modification is exerted by tissue-specific coactivators of the androgen receptor (216-220). Finally, gene transcription initiated by the activated androgen receptors can be mediated by polymorphisms in the respective promoter regions (221). Thus, serum testosterone levels are only one of many factors forming the cascade of androgen action and all the other factors may follow a pattern independent of serum testosterone levels.

In the studies discussed here, data have been obtained within a confined scope of parameters (Table 1). In most cases, the drastic effects of testosterone substitution in hypogonadal men are mirrored in eugonadal men by somewhat weaker correlations of endogenous testosterone levels with various aspects. Because of the great inter-individual 


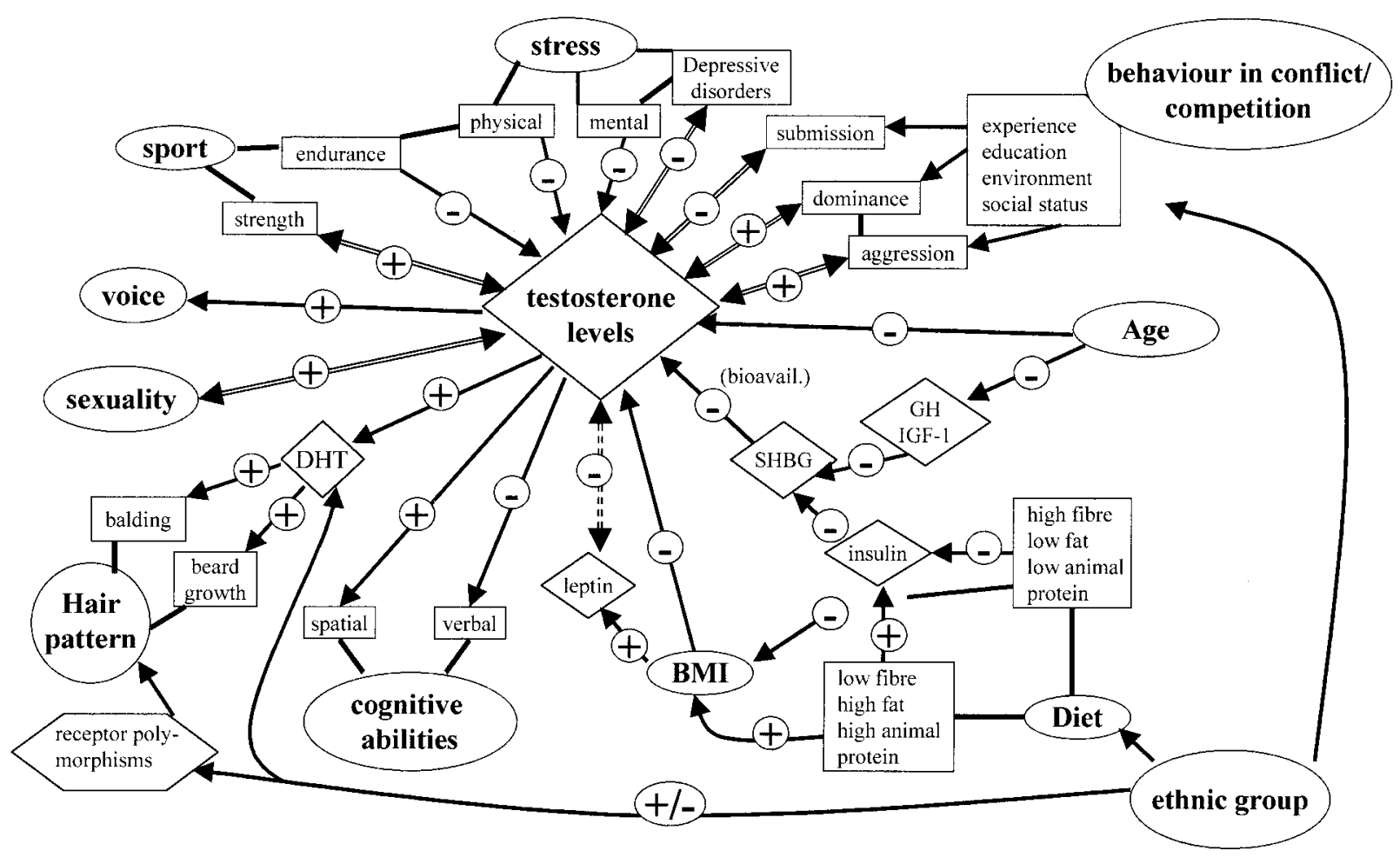

Figure 3 Interactions and feedback-mechanisms of testosterone levels with behavioural and physical dimensions. Arrows indicate the direction of influence, plus or minus signs imply the nature of impact. GH, growth hormone; IGF-1, insulin-like growth factor type 1; DHT, dihydrostestosterone.

variation, application of these results to individuals is questionable. A generalisation towards phenomenological structures would also require sublimation of various one-dimensional findings. Combining results concerning hormone interactions with physical or psychological phenomena to create new constructs explaining sociological observations can be dangerous and misleading. It is too easy a step from assigning high testosterone levels to aggressive people to the explanation of legal offences of violent nature and further, discrimination of racial or subcultural groups. This could mean, for example, that persons involved in regular marathon training are likely to show a submissive kind of conflict management and will not develop a balding hair pattern, or that watching blue movies would lead to premature balding which could then be prevented by a strict vegetarian diet or by moving to the mountains. It could mean that a man exposed to increased mental stress is likely to show extraordinary verbal fluency.

Regarding all results mentioned, a person with high testosterone levels would then be living at sea level, would refrain from endurance training, enjoy high socioeconomic status as well as daily consumption of meat and sexual pleasures, but avoid gaining too much weight. He would be characterised by increased spatial cognition, but not be able to utter sentences fluently. He would have a deep voice, sing in the bass register, his beard growth would be prolific and his head would be bald. He would react rather aggressively to threatening situations. A person with low testosterone levels would be a mountaineer, exercising daily by long runs, living a frugal life with vegetarian food, without a partner and constantly harassed by his environment. He would have a full head of hair, a high-pitched voice, and would converse fluently about his submissive behaviour and his lack of ability to solve mathematical problems (see Table 1).

The described persons might exist, but they are likely to be rare, and just how high their actual testosterone levels would really be remains open to question. The rest of the male population cannot be judged by testosterone levels and we cannot guess their androgen levels by looking at their lives.

Simplifying approaches are likely to produce results with simple structures, which, while logically consistent in themselves, do not conform to the external structures we experience. Many other factors of influence are omitted in these approaches such as experiences that are partially reinforced by hormonal feedback on behaviour that caused them and that social and physical environment and genetic background affect not only an individual's personality but also a single parameter such as testosterone levels. 
Hence, levels of this hormone are influenced by conditions which are partly due to control by the hormone itself, but are also affected by conditions which are beyond individual or hormonal control (Fig. 3). Scientific evaluation of androgen action by carefully planned studies which correct for parameters of additional influence has resulted in useful and fascinating information about the interactions between testosterone and, for example behavioural aspects. It should be viewed for what it is: restricted, but valuable, information on certain domains of hormones and their actions, but it should not be manipulated to create constructs about individuals or groups which inevitably fail. A holistic approach allows a careful application of these principles in individual cases but requires various perspectives of the complex picture of psychoendocrinological and sociological interactions.

\section{Acknowledgements}

The authors would like to thank S Nieschlag M.A. for language editing.

\section{References}

1 Sullivan A. The He hormone. The New York Times Magazine 2000, April 2.

2 Hackney AC, Fahrner CL \& Gulledge TP. Basal reproductive hormonal profiles are altered in endurance trained men. Journal of Sports Medicine and Physical Fitness 199838 138-141.

3 Duclos M, Corcuff JB, Rashedi M, Fougere V \& Manier G. Does functional alteration of the gonadotropic axis occur in endurance trained athletes during and after exercise? A preliminary study. European Journal of Applied Physiology 1996 73 427-433.

4 De Souza MJ, Arce JC, Pescatello LS, Scherzer HS \& Luciano AA. Gonadal hormones and semen quality in male runners. A volume threshold effect of endurance training. International Journal of Sports Medicine 199415 383-391.

5 Hackney AC, Sinning WE \& Bruot BC. Hypothalamic-pituitarytesticular axis function in endurance-trained males. International Journal of Sports Medicine 199011 298-303.

6 Wheeler GD, Wall SR, Belcastro AN \& Cumming DC. Reduced serum testosterone and prolactin levels in male distance runners. Journal of the American Medical Association 198427 514-516.

7 Berchtold P, Berger M, Cuppers HJ, Herrmann J, Nieschlag E, Rudorff $\mathrm{K}$ et al. Non-glucoregulatory hormones (T4, T3, rT3, TSH, testosterone) during physical exercise in juvenile type diabetics. Hormone and Metabolic Research 197810 269-273.

8 Fournier PE, Stalder J, Mermillod B \& Chantraine A. Effects of a 110 kilometers ultra-marathon race on plasma hormone levels. International Journal of Sports Medicine $199718252-256$.

9 Schürmeyer T, Jung K \& Nieschlag E. The effect of an $1100 \mathrm{~km}$ run on testicular adrenal and thyroid hormones. International Journal of Andrology $19847276-282$.

10 Chicharro JL, Lopez-Mojares LM, Lucia A, Perez M, Alvarez J, Labanda $\mathrm{P}$ et al. Overtraining parameters in special military units. Aviation Space and Environmental Medicine $199869562-$ 568 .

11 Marinelli M, Roi GS, Giacometti M, Bonini P \& Banfi G. Cortisol testosterone and free testosterone in athletes performing a marathon at $4000 \mathrm{~m}$ altitude. Hormone Research $1994 \mathbf{4 1}$ 225-229.
12 Vervoorn C, Quist AM, Vermulst LJ, Erich WB, de Vries WR \& Thijssen JH. The behaviour of the plasma free testosterone/ cortisol ratio during a season of elite rowing training. International Journal of Sports Medicine 199112 257-263.

13 Singh A, Petrides JS, Gold PW, Chrousos GP \& Deuster PA. Differential hypothalamic-pituitary-adrenal axis reactivity to psychological and physical stress. Journal of Clinical Endocrinology and Metabolism $1999 \mathbf{8 4} 1944-1948$.

14 Opstad PK. The hypothalamo-pituitary regulation of androgen secretion in young men after prolonged physical stress combined with energy and sleep deprivation. Acta Endocrinol (Copenhagen) $1992127231-236$.

15 Bernton E, Hoover D, Galloway R \& Popp K. Adaptation to chronic stress in military trainees. Adrenal androgens, testosterone, glucocorticoids, IGF-1 and immune function. Annals of the New York Academy of Sciences 199529 217-231.

16 Baumgartner RN, Waters DL, Gallagher D, Morley JE \& Garry PJ. Predictors of skeletal muscle mass in elderly men and women. Mechanisms of Ageing and Development 1999 107 123-136.

17 Ramos E, Frontera WR, Llopart A \& Feliciano D. Muscle strength and hormonal levels in adolescents: gender related differences. International Journal of Sports Medicine 199819 526-531.

18 Kraemer WJ, Staron RS, Hagerman FC, Hikida RS, Fry AC, Gordon SE et al. The effects of short-term resistance training on endocrine function in men and women. European Journal of Applied Physiology $1998 \mathbf{7 8}$ 69-76.

19 Hakkinen K, Pakarinen A, Newton RU \& Kraemer WJ. Acute hormone responses to heavy resistance lower and upper extremity exercise in young versus old men. European Journal of Applied Physiology 199877 312-319.

20 Kraemer RR, Kilgore JL, Kraemer GR \& Castracane VD. Growth hormone IGF-I and testosterone responses to resistive exercise. Medicine and Science in Sports and Exercise 199224 1346-1352.

21 Jurimae T, Karelson K, Smirnova T \& Viru A. The effect of a single-circuit weight-training session on the blood biochemistry of untrained university students. European Journal of Applied Physiology 199061 344-348.

22 Bhasin S, Storer TW, Berman N, Callegari C, Clevenger B \& Phillips J. The effects of supraphysiologic doses of testosterone on muscle size and strength in normal men. New England Journal of Medicine $19963351-7$.

23 Craig BW, Brown R \& Everhart J. Effects of progressive resistance training on growth hormone and testosterone levels in young and elderly subjects. Mechanisms of Ageing and Development 1989 49 159-169.

24 Fry AC, Kraemer WJ \& Ramsey LT. Pituitary-adrenal-gonadal responses to high-intensity resistance exercise overtraining. Journal of Applied Physiology $1998 \mathbf{8 5} 2352-2359$.

25 Bhasin S, Bross R, Storer TW \& Casaburi R. Androgens and muscles. In Testosterone: Action Deficiency Substitution, edn. 2, ch 7, pp 209-228. Eds E Nieschlag \& HM Behre. Berlin: Springer, 1998.

26 Bhasin S, Storer TW, Berman N, Yarasheski KE, Clevenger B, Phillips $\mathrm{J}$ et al. Testosterone replacement increases fat-free mass and muscle size in hypogonadal men. Journal of Clinical Endocrinology and Metabolism 199782 407-413.

27 Wang C, Eyre DR, Clark R, Kleinberg D, Newman C, Iranmanesh A et al. Sublingual testosterone replacement improves muscle mass and strength, decreases bone resorption and increases bone formation markers in hypogonadal men-a clinical research center study. Journal of Clinical Endocrinology and Metabolism $1996 \mathbf{8 1} 3654-3662$.

28 Snyder PJ, Peachey H, Hannoush P, Berlin JA, Loh L, Lenrow DA et al. Effect of testosterone treatment on body composition and muscle strength in men over 65 years of age. Journal of Clinical Endocrinology and Metabolism $1999842647-2653$.

29 Clague JE, Wu FC \& Horan MA. Difficulties in measuring the effect of testosterone replacement therapy on muscle function in older men. International Journal of Andrology 199922 261-265. 
30 Singer F \& Zumoff B. Subnormal serum testosterone levels in male internal medicine residents. Steroids 199257 86-89.

31 Chatterton RT Jr, Vogelsong KM, Lu YC \& Hudgens GA. Hormonal responses to psychological stress in men preparing for skydiving. Journal of Clinical Endocrinology and Metabolism 199782 2503-2509.

32 Chatterton RT Jr \& Dooley SL. Reversal of diurnal cortisol rhythm and suppression of plasma testosterone in obstetric residents on call. Journal of the Society for Gynecological Investigation $1999650-54$.

33 Tegelman R, Carlstrom K \& Pousette A. Hormone levels in male ice hockey players during a $26-\mathrm{h}$ cup tournament. International Journal of Andrology 198811 361-368.

34 Schulz P, Walker JP, Peyrin L, Soulier V, Curtin F \& Steimer T. Lower sex hormones in men during anticipatory stress. Neuroreport 199625 3101-3104.

35 Francis KT. The relationship between high and low trait psychological stress, serum testosterone and serum cortisol. Experientia 198137 1296-1297.

36 Nilsson PM, Moller L \& Solstad K. Adverse effects of psychosocial stress on gonadal function and insulin levels in middle-aged males. Journal of Internal Medicine 1995237 479-486.

37 MacLean CR, Walton KG, Wenneberg SR, Levitsky DK, Mandarino JP, Waziri $\mathrm{R}$ et al. Effects of the transcendental meditation program on adaptive mechanisms: changes in hormone levels and responses to stress after 4 months of practice. Psychoneuroendocrinology 199722 277-295.

38 Grossi G, Theorell T, Jurisoo M \& Setterlind S. Psychophysiological correlates of organizational change and threat of unemployment among police inspectors. Integrative Physiological and Behavioral Science 199934 30-42.

39 Hardy MP \& Ganjam VK. Stress, 11beta-HSD and Leydig cell function. Journal of Andrology 199718 475-479.

40 Rejeski WJ, Brubaker PH, Herb RA, Kaplan JR \& Koritnik DJ. Anabolic steroids and aggressive behaviour in cynomolgus monkeys. Behavioral Medicine 198811 95-105.

41 Brooks JH \& Reddon JR. Serum testosterone in violent and nonviolent young offenders. Journal of Clinical Psychology 1996 52 475-483.

42 Kreuz LE \& Rose RM. Assessment of aggressive behaviour and plasma testosterone in a young criminal population. Psychosomatic Medicine 197234 321-332.

43 Ehrenkranz J, Bliss E \& Sheard MH. Plasma testosterone correlation with aggressive behaviour and social dominance in man. Psychosomatic Medicine 197436 469-474.

44 Virkkunen M, Kallio E, Rawlings R, Tokola R, Poland RE, Guidotti A et al. Personality profiles and state aggressiveness in Finnish alcoholic violent offenders fire setters and healthy volunteers. Archives of General Psychiatry 199451 28-33.

45 Bergman B \& Brismar B. Characteristics of imprisoned wifebeaters. Forensic Science International 199413 157-167.

46 Banks T \& Dabbs JM Jr. Salivary testosterone and cortisol in a delinquent and violent urban subculture. Journal of the Society of Psychology 1996136 49-56.

47 Aromaki AS, Lindman RE \& Eriksson CJP. Testosterone aggressiveness and antisocial personality. Aggressive Behavior 199925 113-123.

48 Monti PM, Brown WA \& Corriveau DP. Testosterone and components of aggressive and sexual behaviour in man. American Journal of Psychiatry 1977134 692-694.

49 Scaramella TJ \& Brown WA. Serum testosterone and aggressiveness in hockey players. Psychosomatic Medicine $1978 \mathbf{4 0}$ 262-265.

50 Cohen D, Nisbett RE, Bowdle BF \& Schwarz N. Insult aggression and the southern culture of honor: an 'experimental ethnography'. Journal of Personality and Social Psychology 199670 945-959.

51 Hellhammer DH, Hubert W \& Schürmeyer T. Changes in saliva testosterone after psychological stimulation in men. Psychoneuroendocrinology 198510 77-81.
52 Archer J. The influence of testosterone on human aggression. British Journal of Psychology 199182 1-28.

53 Adler L, Wedekind D, Pilz J, Weniger G \& Huether G. Endocrine correlates of personality traits: a comparison between emotionally stable and emotionally labile healthy young men. Neuropsychobiology 199735 205-210.

54 Pope HG Jr, Kouri EM \& Hudson JI. Effects of supraphysiologic doses of testosterone on mood and aggression in normal men: a randomized controlled trial. Archives of General Psychiatry 2000 57 133-140.

55 Christiansen K. Behavioural correlates of testosterone. In Testosterone: Action Deficiency Substitution, edn. 2, ch 3, pp 107-142. Eds E Nieschlag \& HM Behre. Berlin: Springer, 1998.

56 Kouri EM, Lukas SE, Pope HG Jr \& Oliva PS. Increased aggressive responding in male volunteers following the administration of gradually increasing doses of testosterone cypionate. Drug and Alcohol Dependence $1995 \mathbf{4 0} 73-79$.

57 Tricker R, Casaburi R, Storer TW, Clevenger B, Berman N, Shirazi A et al. The effects of supraphysiological doses of testosterone on angry behaviour in healthy eugonadal men-a clinical research center study. Journal of Clinical Endocrinology and Metabolism $1996 \mathbf{8 1}$ 3754-3758.

58 Nieschlag E. Testosteron Anabolika und aggressives Verhalten bei Männern. Deutsches Ärzteblatt 199289 2967-2972.

59 Burris AS, Banks SM, Carter CS, Davidson JM \& Sherins RJ. A long-term prospective study of the physiologic and behavioural effects of hormone replacement in untreated hypogonadal men. Journal of Andrology 199213 297-304.

60 Schweiger U, Deuschle M, Weber B, Korner A, Lammers CH, Schmider J et al. Testosterone gonadotropin and cortisol secretion in male patients with major depression. Psychosomatic Medicine $199961292-296$.

61 Unden F, Ljunggren JG, Beck-Friis J, Kjellman BF \& Wetterberg L. Hypothalamic-pituitary-gonadal axis in major depressive disorders. Acta Psychiatrica Scandinavica 198878 138-146.

62 Yehuda R, Teicher MH, Trestman RL, Levengood RA \& Siever LJ. Cortisol regulation in posttraumatic stress disorder and major depression: a chronobiological analysis. Biological Psychiatry $19961579-88$

63 Maes M, Lin A, Bonaccorso S, van Hunsel F, Van Gastel A, Delmeire L et al. Increased 24-h urinary cortisol excretion in patients with post-traumatic stress disorder and patients with major depression but not in patients with fibromyalgia. Acta Psychiatrica Scandinavica 199898 328-335.

64 Vogel W, Klaiber EL \& Brovermann DM. Roles of the gonadal steroid hormones in psychiatric depression in men and women. Progressions in Neurology and Psychopharmacology 19782 487503.

65 Seidman SN \& Rabkin JG. Testosterone replacement therapy for hypogonadal men with SSRI-refractory depression. Journal of Affective Disorders $1998 \mathbf{4 8} 157-161$.

66 Hyde JS, Fennema E \& Lamon SJ. Gender differences in mathematics performance: a meta-analysis. Psychological Bulletin 1990107 139-155.

67 McGlone J. Sex differences in human brain organization: a critical survey. Behavioral and Brain Sciences $19803215-227$.

68 Hassler M, Gupta D \& Wollmann H. Testosterone, estradiol, ACTH and musical, spatial and verbal performance. International Journal of Neuroscience 199265 45-60.

69 Voyer D, Voyer S \& Bryden MP. Magnitude of sex differences in spatial abilities: a meta-analysis and consideration of critical variables. Psychological Bulletin 1995117 250-270.

70 Karadi K, Szabo I, Szepesi T, Kallai J \& Kovacs B. Sex differences on the hand mental rotation task for 9-yr-old children and young adults. Perceptual and Motor Skills 199989 969-972.

71 Crucian GP \& Berenbaum SA. Sex differences in right hemisphere tasks. Brain and Cognition 199836 377-389.

72 Collins DW \& Kimura D. A large sex difference on a twodimensional mental rotation task. Behavioral Neuroscience 1997 $111845-849$ 
73 Neave N, Menaged M \& Weightman DR. Sex differences in cognition: the role of testosterone and sexual orientation. Brain and Cognition $199941245-262$.

74 Levy J \& Reid M. Variations in cerebral organization as a function of handedness, hand posture in writing, and sex. Journal of Experimental Psychology: General 1978 107 119-144.

75 Harris IM, Egan GF, Sonkkila C, Tochon-Danguy HJ, Paxinos G \& Watson JD. Selective right parietal lobe activation during mental rotation: a parametric PET study. Brain 2000123 65-73.

76 Alivisatos B \& Petrides M. Functional activation of the human brain during mental rotation. Neuropsychologia $199735111-$ 118.

77 Silverman I, Kastuk D, Choi J \& Phillips K. Testosterone levels and spatial ability in men. Psychoneuroendocrinology 199924 813-822.

78 Christiansen K \& Knussmann R. Sex hormones and cognitive functioning in men. Neuropsychobiology 198718 27-36.

79 Moffat SD \& Hampson E. A curvilinear relationship between testosterone and spatial cognition in humans: possible influence of hand preference. Psychoneuroendocrinology 199621 323-337.

80 Gouchie C \& Kimura D. The relationship between testosterone levels and cognitive ability patterns. Psychoneuroendocrinology $199116323-334$.

81 Kimura D \& Hampson E. Cognitive pattern in men and women is influenced by fluctuations in sex hormones. Current Opinions in Psychological Sciences 19943 57-61.

82 Gordon HW, Stoffer DS \& Lee PA. Ultradian rhythms in performance on tests of specialized cognitive functions. International Journal of Neuroscience 199583 199-211.

83 Slabbekoorn D, van Goozen SH, Megens J, Gooren LJ \& CohenKettenis PT. Activating effects of cross-sex hormones on cognitive functioning: a study of short-term and long-term hormone effects in transsexuals. Psychoneuroendocrinology 1999 24 423-447.

84 Imperato-McGinley J, Pichardo M, Gautier T, Voyer D \& Bryden MP. Cognitive abilities in androgen-insensitive subjects: comparison with control males and females from the same kindred. Clinical Endocrinology 199134 341-347.

85 Alexander GM, Swerdloff RS, Wang C, Davidson T, McDonald V, Steiner B et al. Androgen-behaviour correlations in hypogonadal men and eugonadal men II Cognitive abilities. Hormones and Behavior 199833 85-94.

86 Buchsbaum MS \& Henkin RI. Perceptual abnormalities in patients with chromatin negative gonadal dysgenesis and hypogonadotropic hypogonadism. International Journal of Neuroscience $198011201-209$.

87 Hier DB \& Crowley WF Jr. Spatial ability in androgen-deficient men. New England Journal of Medicine 1982306 1202-1205.

88 Janowsky JS, Oviat SK \& Orwoll ES. Testosterone influences spatial cognition in older men. Behavioral Neuroscience 1994 $108325-332$.

89 Zitzmann M, Weckesser M, Schober O \& Nieschlag E. Testosterone-induced changes in cerebral glucose metabolism: association with visuospatial capability (submitted).

90 Wolf OT, Preut R, Hellhammer DH, Kudielka BM, Schurmeyer TH \& Kirschbaum C. Testosterone and cognition in elderly men: a single testosterone injection blocks the practice effect in verbal fluency, but has no effect on spatial or verbal memory. Biological Psychiatry 200047 650-654.

91 Miles C, Green R, Sanders G \& Hines M. Estrogen and memory in a transsexual population. Hormones and Behavior $19983 \mathbf{4}$ 199-208.

92 Wolf OT, Kudielka BM, Hellhammer DH, Torber S, McEwen BS \& Kirschbaum C. Two weeks of transdermal estradiol treatment in postmenopausal elderly women and its effect on memory and mood: verbal memory changes are associated with the treatment induced estradiol levels. Psychoneuroendocrinology 199924 727-741.

93 Carlson LE \& Sherwin BB. Higher levels of plasma estradiol and testosterone in healthy elderly men compared with age-matched women may protect aspects of explicit memory. Menopause 20007 168-177.

94 Resnick SM, Maki PM, Golski S, Kraut MA \& Zonderman AB. Effects of estrogen replacement therapy on PET cerebral blood flow and neuropsychological performance. Hormones and Behavior 199834 171-182.

95 Hassler M. Creative musical behaviour and sex hormones: musical talent and spatial ability in the two sexes. Psychoneuroendocrinology 199217 55-70.

96 Hassler M \& Nieschlag E. Masculinity, femininity and musical composition, psychological and psychoendocrinological aspects of musical and spatial faculties. Archiv fuer Psychologie 1989 $14171-84$

97 Wickings EJ \& Dixson AF. Testicular function secondary sexual development and social status in male mandrills (Mandrillus sphinx). Physiology and Behavior 199252 909-916.

98 Winslow JT, Ellingboe J \& Miczek KA. Effects of alcohol on aggressive behaviour in squirrel monkeys: influence of testosterone and social context. Psychopharmacology (Berl) 198895 356-363.

99 Schaal B, Tremblay RE, Soussignan R \& Susman EJ. Male testosterone linked to high social dominance but low physical aggression in early adolescence. Journal of the American Academy of Child and Adolescent Psychiatry 199635 1322-1330.

100 Fellmann N, Beaune B \& Coudert J. Blood lactate after maximal and supramaximal exercise in 10- to 12-year-old Bolivian boys. Effects of altitude and socioeconomic status. International Journal of Sports Medicine 199415 (Suppl 2) S90-S95.

101 Theorell T, Ahlberg HG, Sigala F, Perski A, Soderholm M, Kallner A et al. Psychosocial and biomedical comparison between men in six contrasting service occupations. Work Stress $1990 \mathbf{4} 51-63$.

102 Mazur A, Booth A \& Dabbs JM Jr. Testosterone and chess competition. Social Psychology Quarterly 199255 70-77.

103 Mazur A \& Lamb TA. Testosterone status and mood in human males. Hormones and Behavior $198014236-246$.

104 Elias M. Serum cortisol testosterone and testosterone binding globulin responses to competitive fighting human males. Aggressive Behaviour 19817 215-224.

105 Suay F, Salvador A, Gonzalez-Bono E, Sanchis C, Martinez M, Martinez-Sanchis S et al. Effects of competition and its outcome on serum testosterone cortisol and prolactin. Psychoneuroendocrinology 199924 551-566.

106 Dabbs JM Jr \& Morris R. Testosterone social class and antisocial behaviour in a sample of 4462 men. Psychological Science 1990 1 209-211.

107 Dabbs JM Jr. Testosterone and occupational achievement. Social Forces $1992 \mathbf{7 0} 813-824$.

108 Studer LH, Reddon JR \& Siminoski KG. Serum testosterone in adult sex offenders: a comparison between Caucasians and North American Indians. Journal of Clinical Psychology 199753 375-385.

109 Rushton JP. Race and crime: an international dilemma. Society 199532 37-41.

110 Zagars GK, Pollack A \& Pettaway CA. Prostate cancer in African-American men: outcome following radiation therapy with or without adjuvant androgen ablation. International Journal of Radiation Oncology Biology Physics 199842 517-523.

111 Gombe S \& Ndeti CS. Plasma testosterone and progesterone levels in adult East Africans. East African Medical Journal 1976 53 43-46.

$112 \mathrm{Wu}$ AH, Whittemore AS, Kolonel LN, John EM, Gallagher RP, West DW et al. Serum androgens and sex hormone-binding globulins in relation to lifestyle factors in older AfricanAmerican, white and Asian men in the United States and Canada. Cancer Epidemiology Biomarkers and Prevention 19954 735-741.

113 Cussenot O, Valeri A, Berthon P, Fournier G \& Mangin P Hereditary prostate cancer and other genetic predispositions to prostate cancer. Urology International 601998 30-34. 
114 Hikim AP, Wang C, Lue Y, Johnson L, Wang XH \& Swerdloff RS. Spontaneous germ cell apoptosis in humans: evidence for ethnic differences in the susceptibility of germ cells to programmed cell death. Journal of Clinical Endocrinology and Metabolism $1998 \mathbf{8 3}$ $152-156$.

115 Wang Q, Ghadessy FJ \& Yong EL. Analysis of the transactivation domain of the androgen receptor in patients with male infertility. Clinical Genetics 199854 185-192.

116 Johnson L, Barnard JJ, Rodriguez L, Smith EC, Swerdloff RS, Wang XH et al. Ethnic differences in testicular structure and spermatogenic potential may predispose testes of Asian men to a heightened sensitivity to steroidal contraceptives. Journal of Andrology 199819 348-357.

117 Hill P, Wynder EL, Garbaczewski L, Garnes H \& Walker AR. Diet and urinary steroids in black and white North American men and black South African men. Cancer Research 197939 5101-5105.

118 Gooren LJ. Androgen levels and sex functions in testosteronetreated hypogonadal men. Archives of Sexual Behavior 198716 463-473.

119 Clopper RR, Voorhess ML, MacGillivray MH, Lee PA \& Mills B. Psychosexual behaviour in hypopituitary men: a controlled comparison of gonadotropin and testosterone replacement. Psychoneuroendocrinology 199318 149-161.

120 Bals-Pratsch M, Langer K, Place VA \& Nieschlag E. Substitution therapy of hypogonadal men with transdermal testosterone over one year. Acta Endocrinologica 1988118 7-13.

121 Persky H, Lief HI, Strauss D, Miller WR \& O'Brien CP. Plasma testosterone level and sexual behaviour of couples. Archives of Sexual Behavior 19787 157-173.

122 Anderson RA, Bancroft J \& Wu FC. The effects of exogenous testosterone on sexuality and mood of normal men. Journal of Clinical Endocrinology and Metabolism 199275 1503-1507.

123 Alexander GM, Swerdloff RS, Wang C, Davidson T, McDonald V, Steiner B et al. Androgen-behaviour correlations in hypogonadal men and eugonadal men I. Mood and response to auditory sexual stimuli. Hormones and Behavior 199731 110119.

124 Stoléru SG, Ennaji A, Cournot A \& Spira A. LH pulsatile secretion and testosterone blood levels are influenced by sexual arousal in human males. Psychoneuroendocrinology 199318 205-218.

125 Stoléru S, Gregoire MC, Gerard D, Decety J, Lafarge E, Cinotti L et al. Neuroanatomical correlates of visually evoked sexual arousal in human males. Archives of Sexual Behavior 199928 $1-21$.

126 James S, Carter RA \& Orwin A. Significance of androgen levels in the aetiology and treatment of homosexuality. Psychological Medicine 1977 7 427-429.

127 Rohde W, Stahl F \& Dörner G. Plasma basal levels of FSH, LH and testosterone in homosexual men. Endokrinologie $1977 \mathbf{7 0}$ 241-248.

128 Doerr P, Pirke KM, Kockott G \& Dittmar F. Further studies on sex hormones in male homosexuals. Archives of General Psychiatry $197633611-614$.

129 Dörner G. Neuroendocrine response to estrogen and brain differentiation in heterosexuals, homosexuals and transsexuals. Archives of Sexual Behavior 198817 57-75.

130 Elias AN \& Valenta LJ. Are all males equal? Anatomic and functional basis for sexual orientation in males. Medical Hypotheses $19923985-87$.

131 Headings VE. Etiology of homosexuality. Southern Medical Journal 198073 1024-1027.

132 Dörner G, Docke F, Gotz F, Rohde W, Stahl F \& Tonjes R. Sexual differentiation of gonadotrophin secretion, sexual orientation and gender role behaviour. Journal of Steroid Biochemistry and Molecular Biology 198727 1081-1087.

133 Giordano G \& Giusti M. Hormones and psychosexual differentiation. Minerva Endocrinologica 199520 165-193.

134 Schmidt G \& Clement U. Does peace prevent homosexuality? Journal of Homosexuality 199528 269-275.
135 Banks A \& Gartrell NK. Hormones and sexual orientation: a questionable link. Journal of Homosexuality 199528 247-268.

136 Meyer WJ 3d, Cole C \& Emory E. Depo provera treatment for sex offending behaviour: an evaluation of outcome. Bulletin of the American Academy of Psychiatry and the Law 199220 249-259.

137 Rada RT, Laws DR, Kellner R, Stivastava L \& Peake G. Plasma androgens in violent and nonviolent sex offenders. Bulletin of the American Academy of Psychiatry and the Law 198311 149-158.

138 Bradford JM \& McLean D. Sexual offenders violence and testosterone: a clinical study. Canadian Journal of Psychiatry $198429335-343$

139 Rada RT, Laws DR \& Kellner R. Plasma testosterone levels in the rapist. Psychosomatic Medicine 197638 257-268.

140 Christiansen K \& Knussmann R. Androgen levels and components of aggressive behaviour in men. Hormones and Behavior 198721 170-180.

141 Sourial N \& Fenton F. Testosterone treatment of an XXYY male presenting with aggression: a case report. Canadian Journal of Psychiatry 198833 846-850.

142 Bernstein R, Berman IW \& Nurse GT. An XXYY male presenting with aggression: a case report. South African Medical Journal 197752 809-812.

143 Beckmann J, Dupont A, Erling I, Jacobsen P, Mikkelsen M \& Theilgaard A. Report of sex chromosome abnormalities in mentally retarded male offenders including a psychological study of patients with XYY and XXYY karyotypes. Journal of Mental Deficiency Research 197418 331-353.

144 Nielsen J, Pelsen B \& Sorensen K. Follow-up of 30 Klinefelter males treated with testosterone. Clinical Genetics $198833262-$ 269.

145 Seim HC \& Dwyer M. Evaluation of serum testosterone and luteinizing hormone levels in sex offenders. Family Practice Research Journal 19887 175-180.

146 Shostakovich BV, Smirnova LK, Tkachenko AA, Ushakova IM, Kartelishev AV \& Nikolaeva TN. A comparative evaluation of the biochemical and psychopathological characteristics in subjects with signs of pedophilia. Zhurnal Nevropatologii I Psikhiatrii Imeni S.S. Korsakova 199292 83-88.

147 Nieschlag E, Kley HK, Wiegelmann W, Solbach HG \& Krüskemper HL. Age and endocrine function of the testes in adult man. Deutsche Medizinische Wochenschrift $1973291281-$ 1284.

148 Nieschlag E, Lammers U, Freischem CW, Langer K \& Wickings EJ. Reproductive functions in young fathers and grandfathers. Journal of Clinical Endocrinology and Metabolism 198255 676681 .

149 Vermeulen A \& Deslypere JP. Testicular endocrine function in the ageing male. Maturitas 19857 273-279.

150 Schiavi RC, Schreiner-Engel P, White D \& Mandeli J. The relationship between pituitary-gonadal function and sexual behaviour in healthy aging men. Psychosomatic Medicine 1991 53 363-374

151 Zitzmann M, Behre HM \& Nieschlag E. Choice of testosterone preparation for the management of the aging male. In Endocrine Basis of Reproductive Function, edn 1, pp 551-567. Ed. M Filicori. Monduzzi, Italy, 2000.

152 Vermeulen A, Kaufman JM \& Giagulli VA. Influence of some biological indexes on sex hormone-binding globulin and androgen levels in aging or obese males. Journal of Clinical Endocrinology and Metabolism 199681 1821-1826.

153 Morley JE, Kaiser FE, Perry HM 3rd, Patrick P, Morley PM, Stauber PM et al. Longitudinal changes in testosterone luteinizing hormone and follicle-stimulating hormone in healthy older men. Metabolism 199746 410-413.

154 Kaufman JM \& Vermeulen A. Androgens in male senescence. In Testosterone: Action Deficiency Substitution, edn. 2, ch 16, pp 437-472. Eds E Nieschlag \& HM Behre. Berlin: Springer, 1998.

155 Longcope C, Feldman HA, McKinlay JB \& Araujo AB. Diet and sex hormone-binding globulin. Journal of Clinical Endocrinology and Metabolism 2000 85 293-296. 
156 Giagulli VA, Kaufman JM \& Vermeulen A. Pathogenesis of the decreased androgen levels in obese men. Journal of Clinical Endocrinology and Metabolism 199479 997-1000.

157 Barrett-Connor E, Khaw KT \& Yen SS. Endogenous sex hormone levels in older adult men with diabetes mellitus. American Journal of Epidemiology 1990132 895-901.

158 Behre HM, Simoni M \& Nieschlag E. Strong association between serum levels of leptin and testosterone in men. Clinical Endocrinology 199747 237-240.

159 Finn PD, Cunningham MJ, Pau KY, Spies HG, Clifton DK \& Steiner RA. The stimulatory effect of leptin on the neuroendocrine reproductive axis of the monkey. Endocrinology 1998139 $4652-4662$.

160 Belanger A, Locong A, Noel C, Cusan L, Dupont A, Prevost J et al. Influence of diet on plasma steroids and sex hormone-binding globulin levels in adult men. Journal of Steroid Biochemistry and Molecular Biology 198932 829-833.

161 Key TJ, Roe L, Thorogood M, Moore JW, Clark GM \& Wang DY. Testosterone sex hormone-binding globulin, calculated free testosterone and oestradiol in male vegans and omnivores. British Journal of Nutrition $1990 \mathbf{6 4} 111-119$.

162 Bishop DT, Meikle AW, Slattery ML, Stringham JD, Ford MH \& West DW. The effect of nutritional factors on sex hormone levels in male twins. Genetic Epidemiology 19885 43-59.

163 Reed MJ, Cheng RW, Simmonds M, Richmond W \& James VH. Dietary lipids: an additional regulator of plasma levels of sex hormone binding globulin. Journal of Clinical Endocrinology and Metabolism 198764 1083-1085.

164 Meikle AW, Stringham JD, Woodward MG \& McMurry MP. Effects of a fat-containing meal on sex hormones in men. Metabolism 199039 943-946.

165 Haffner SM, Valdez RA, Mykkanen L, Stern MP \& Katz MS. Decreased testosterone and dehydroepiandrosterone sulfate concentrations are associated with increased insulin and glucose concentrations in nondiabetic men. Metabolism 1994 43 599-603.

166 Sawhney RC, Chabra PC, Malhotra AS, Singh T, Riar SS \& Rai RM. Hormone profiles at high altitude in man. Andrologia $198517178-184$

167 Basu M, Pal K, Prasad R, Malhotra AS, Rao KS \& Sawhney RC. Pituitary gonadal and adrenal hormones after prolonged residence at extreme altitude in man. International Journal of Andrology 199720 153-158.

168 Ajlouni KM, Sliman NA, Najdawi A, Abu-Hajir MM \& Arnaout MA. Effect of exposure to the altitude of 300 meters below sea-level on testosterone, luteinizing hormone, folliclestimulating hormone and prolactin in man. Journal of Endocrinological Investigation 198811 621-623.

169 Harries ML, Walker JM, Williams DM, Hawkins S \& Hughes IA. Changes in the male voice at puberty. Archives of Disease in Childhood 199777 445-447.

170 Pedersen MF, Moller S, Krabbe S \& Bennett P. Fundamental voice frequency measured by electroglottography during continuous speech. A new exact secondary sex characteristic in boys in puberty. International Journal of Pediatric Otorhinolaryngology 198611 21-27.

171 Meuser W \& Nieschlag E. Sex hormones and depth of voice in the male. Deutsche Medizinische Wochenschrift 197725 261264.

172 Randall VA. Androgens and hair. In Testosterone: Action Deficiency Substitution, edn 2, ch 5, pp 169-186. Eds E Nieschlag \& HM Behre. Berlin: Springer, 1998.

173 Hibberts NA, Howell AE \& Randall VA. Balding hair follicle dermal papilla cells contain higher levels of androgen receptors than those from non-balding scalp. Journal of Endocrinology $199815659-65$.

174 Randall VA, Thornton MJ, Hamada K \& Messenger AG. Mechanism of androgen action in cultured dermal papilla cells derived from human hair follicles with varying responses to androgens in vivo. Journal of Investigative Dermatology 98 (6 Suppl) 1992 86S-91S.

175 Kaufman KD, Olsen EA, Whiting D, Savin R, DeVillez R, Bergfeld $W$ et al. Finasteride in the treatment of men with androgenetic alopecia. Finasteride Male Pattern Hair Loss Study Group. Journal of the American Academy of Dermatology 199839 $578-589$.

176 Demark-Wahnefried W, Lesko SM, Conaway MR, Robertson CN, Clark RV, Lobaugh B et al. Serum androgens: associations with prostate cancer risk and hair patterning. Journal of Andrology 199718 495-500.

177 Knussmann R, Christiansen K \& Kannmacher J. Relations between sex hormone level and characters of hair and skin in healthy young men. American Journal of Physical Anthropology 199288 59-67.

178 Dong Q, Hawker F, McWilliam D, Bangah M, Burger H \& Handelsman DJ. Circulating immunoreactive inhibin and testosterone levels in men with critical illness. Clinical Endocrinology 199236 399-404.

179 Handelsman DJ \& Staraj S. Testicular size: the effects of aging, malnutrition and illness. Journal of Andrology 19856 144-151.

180 Handelsman DJ \& Dong Q. Hypothalamo-pituitary gonadal axis in chronic renal failure. Endocrinology and Metabolism Clinics of North America 199322 145-161.

181 Handelsman DJ. Strasser S, McDonald JA, Conway AJ \& McCaughan GW. Hypothalamic-pituitary-testicular function in end-stage non-alcoholic liver disease before and after liver transplantation. Clinical Endocrinology 199543 331-337.

182 Zelissen PM, van Hattum J, Poen H, Scholten P, Gerritse R \& te Velde ER. Influence of salazosulphapyridine and 5-aminosalicylic acid on seminal qualities and male sex hormones. Scandinavian Journal of Gastroenterology 198823 1100-1104.

183 Handelsman DJ. Testicular dysfunction in systemic diseases. In Andrology: Male Reproductive Health and Dysfunction, edn 2, ch 12, pp 227-235. Eds E Nieschlag \& HM Behre. Berlin Heidelberg: Springer, 2000.

184 Liu PY \& Handelsman DJ. Androgen therapy in non-gonadal diseases. In Testosterone: Action Deficiency Substitution, edn. 2, ch 17, pp 473-512. Eds E Nieschlag \& HM Behre. Berlin: Springer, 1998.

185 Fisher CL, Mannino DM, Herman WH \& Frumkin H. Cigarette smoking and thyroid hormone levels in males. International Journal of Epidemiology 199726 972-977.

186 Knussmann R \& Christiansen K. Attributes of masculinity and androgen measures. Homo 198939 45-50.

187 Cushman P Jr. Plasma testosterone levels in healthy male marijuana smokers. American Journal of Drug and Alcohol Abuse $19752269-275$.

188 La Grange L, Jones TD, Erb L \& Reyes E. Alcohol consumption: biochemical and personality correlates in a college student population. Addictive Behaviors 199520 93-103.

189 Sarnyai Z, Dhabhar FS, McEwen BS \& Kreek MJ. Neuroendocrine-related effects of long-term 'binge' cocaine administration: diminished individual differences in stress-induced corticosterone response. Neuroendocrinology 199868 334-344.

190 Rasheed A \& Tareen IA. Effects of heroin on thyroid function, cortisol and testosterone level in addicts. Polish Journal of Pharmacology 199547 441-444.

191 Simoni M, Montanini V, Fustini MF, Del Rio G, Cioni K \& Marrama P. Circadian rhythm of plasma testosterone in men with idiopathic hypogonadotrophic hypogonadism before and during pulsatile administration of gonadotrophin-releasing hormone. Clinical Endocrinology 199236 29-34.

192 Ellison PT \& Panter-Brick C. Salivary testosterone levels among Tamang and Kami males of central Nepal. Human Biology 1996 68 955-965.

193 Gritsko N, Shulga V \& Ivanova L. Diurnal rhythms of the neuroendocrine system in professional riveters with different 
constitutional types. Central European Journal of Public Health $19953132-134$.

194 Nieschlag E \& Ismail AA. Diurnal variations of plasma testosterone in normal and pathological conditions as measured by the technique of competitive protein binding. Journal of Endocrinology 197046 3-4.

195 Behre HM, Klein B, Steinmeyer E, McGregor GP, Voigt K \& Nieschlag E. Effective suppression of luteinizing hormone and testosterone by single doses of the new gonadotropin-releasing hormone antagonist cetrorelix (SB-75) in normal men. Journal of Clinical Endocrinology and Metabolism 199275 393-398.

196 Albertsson-Wikland K, Rosberg S, Lannering B, Dunkel L, Selstam G \& Norjavaara E. Twenty-four-hour profiles of luteinizing hormone, follicle-stimulating hormone, testosterone, and estradiol levels: a semilongitudinal study throughout puberty in healthy boys. Journal of Clinical Endocrinology and Metabolism 199782 541-549.

197 Carlsen E, Olsson C, Petersen JH, Andersson AM \& Skakkebaek NE. Diurnal rhythm in serum levels of inhibin B in normal men: relation to testicular steroids and gonadotropins. Journal of Clinical Endocrinology and Metabolism $1999 \mathbf{8 4}$ 1664-1669.

198 Nieschlag E. Testicular function. In Clinical Laboratory Diagnostics, ch 11, pp 1100-1108. Ed. L Thomas. Frankfurt-Main: THBooks, 1998.

199 Zitzmann M \& Nieschlag E. Hormone substitution in male hypogonadism. Molecular and Cellular Endocrinology 2000161 73-88.

200 Vermeulen A \& Verdonck G. Representativeness of a single point plasma testosterone level for the long term hormonal milieu in men. Journal of Clinical Endocrinology and Metabolism $19927 \mathbf{4}$ 939-942.

201 Meriggiola MC, Noonan EA, Paulsen CA \& Bremner WJ. Annual patterns of luteinizing hormone, follicle stimulating hormone testosterone and inhibin in normal men. Human Reproduction $199611248-252$.

202 Maes M, Mommen K, Hendrickx D, Peeters D, D’Hondt P, Ranjan $\mathrm{R}$ et al. Components of biological variation including seasonality in blood concentrations of TSH, TT3, FT4, PRL, cortisol and testosterone in healthy volunteers. Clinical Endocrinology 199746 587-598.

203 Dabbs JM Jr. Age and seasonal variation in serum testosterone concentration among men. Chronobiology International 19907 245-249.

204 Tschop M, Behre HM, Nieschlag E, Dressendorfer RA \& Strasburger CJ. A time-resolved fluorescence immunoassay for the measurement of testosterone in saliva: monitoring of testosterone replacement therapy with testosterone buciclate. Clinical Chemistry and Laboratory Medicine 199836 223-230.

205 Vermeulen A, Verdonck L \& Kaufman JM. A critical evaluation of simple methods for the estimation of free testosterone in serum. Journal of Clinical Endocrinology and Metabolism $19998 \mathbf{4}$ 3666-3672.

206 Burgos-Trinidad M, Youngblood GL, Maroto MR, Scheller A, Robins DM \& Payne AH. Repression of cAMP-induced expression of the mouse P450 17 alpha-hydroxylase/C17-20 lyase gene (Cyp17) by androgens. Molecular Endocrinology 199711 87-96.

207 Zhai J, Lanclos KD \& Abney TO. Estrogen receptor messenger ribonucleic acid changes during Leydig cell development. Biology of Reproduction 199655 782-788.
208 Agular BM \& Vind C. Effects of dexamethasone on steroidogenesis in Leydig cells from rats of different ages. Journal of Steroid Biochemistry and Molecular Biology 199554 75-81.

209 Le Roy C, Lejeune H, Chuzel F, Saez JM \& Langlois D. Autocrine regulation of Leydig cell differentiated functions by insulin-like growth factor I and transforming growth factor beta. Journal of Steroid Biochemistry and Molecular Biology 199969 379-384.

210 Laslett AL, McFarlane JR \& Risbridger GP. Developmental response by Leydig cells to acidic and basic fibroblast growth factor. Journal of Steroid Biochemistry and Molecular Biology 1997 $60171-179$.

211 Xiong Y \& Hales DB. Expression regulation and production of tumor necrosis factor-alpha in mouse testicular interstitial macrophages in vitro. Endocrinology 1993133 2568-2573.

212 Xue W, Irvine RA, Yu MC, Ross RK, Coetzee GA \& Ingles SA. Susceptibility to prostate cancer: interaction between genotypes at the androgen receptor and prostate-specific antigen loci. Cancer Research 200060 839-841.

$213 \mathrm{Yu} \mathrm{H,} \mathrm{Bharaj} \mathrm{B,} \mathrm{Vassilikos} \mathrm{EJ,} \mathrm{Giai} \mathrm{M} \mathrm{\&} \mathrm{Diamandis} \mathrm{EP.} \mathrm{Shorter}$ CAG repeat length in the androgen receptor gene is associated with more aggressive forms of breast cancer. Breast Cancer Research and Treatment 200059 153-161.

214 Mitsumori K, Terai A, Oka H, Segawa T, Ogura K, Yoshida O et al. Androgen receptor CAG repeat length polymorphism in benign prostatic hyperplasia $(\mathrm{BPH})$ : correlation with adenoma growth. Prostate 199941 253-257.

215 Giovannucci E, Platz EA, Stampfer MJ, Chan A, Krithivas K \& Kawachi I et al. The CAG repeat within the androgen receptor gene and benign prostatic hyperplasia. Urology $199953121-$ 125 .

216 Needham M, Raines S, McPheat J, Stacey C, Ellston J, Hoare S et al. Differential interaction of steroid hormone receptors with LXXLL motifs in SRC-1 a depends on residues flanking the motif. Journal of Steroid Biochemistry and Molecular Biology 200072 35-46.

217 Müller JM, Isele U, Metzger E, Rempel A, Moser M, Pscherer A et al. FHL2 a novel tissue-specific coactivator of the androgen receptor. EMBO Journal 200019 359-369.

218 Lee DK, Duan HO \& Chang C. From androgen receptor to the general transcription factor TFIIH. Identification of cdk activating kinase $(\mathrm{CAK})$ as an androgen receptor $\mathrm{NH}(2)$-terminal associated coactivator. Journal of Biological Chemistry 2000275 9308-9313.

219 Hsiao PW, Lin DL, Nakao R \& Chang C. The linkage of Kennedy's neuron disease to ARA24, the first identified androgen receptor polyglutamine region-associated coactivator. Journal of Biological Chemistry 1999274 20229-20234.

220 Tan JA, Hall SH, Petrusz P \& French FS. Thyroid receptor activator molecule TRAM-1, is an androgen receptor coactivator. Endocrinology 2000141 3440-3450.

221 Lu S, Jenster G \& Epner DE. Androgen induction of cyclindependent kinase inhibitor p21 gene: role of androgen receptor and transcription factor Sp1 complex. Molecular Endocrinology $200014753-760$.

222 UK NEQAS for steroid hormones, Annual Report 1996.

Received 14 June 2000

Accepted 19 October 2000 